\title{
Multiple Cholinergic Markers Are Unexpectedly Not Altered in the Rat Dentate Gyrus following Entorhinal Cortex Lesions
}

\author{
Isabelle Aubert, ${ }^{1,3}$ Judes Poirier, ${ }^{1,2,3,4}$ Serge Gauthier, ${ }^{1,2,4}$ and Rémi Quirion ${ }^{1,2,3,4}$ \\ Departments of 'Neurology and Neurosurgery and ${ }^{2} P$ sychiatry, McGill University, Montreal, Quebec, Canada H3A 2B4, \\ ${ }^{3}$ Douglas Hospital Research Center, Verdun, Quebec, Canada H4H 1R3, and ${ }^{4}$ McGill Center for Studies in Aging, \\ Montreal, Quebec, Canada H3G 1A4
}

\begin{abstract}
Since major cholinergic deficits are observed in Alzheimer's disease, the development of models to study possible choIInergic plasticlty has generated great interest. In this regard, it has been shown that lesions of the entorhinal cortex, which sends glutamatergic projections to the hippocampus, promote the sprouting and plasticity of presumptive cholinergic septohippocampal fibers in the dentate gyrus, as revealed by AChE histochemistry. This sprouting was reported to be evident at $8 \mathrm{~d}$ and up to $30 \mathrm{~d}$ postlesion (DPL) and is now widely used as a model of cholinergic neuronal plasticity. In the present study, unilateral lesions of the entorhinal cortex were made in adult rats, and the status of various putative pre- and postsynaptic cholinergic markers was assessed after 2, 4, 8, 14, and 30 DPL. As expected, AChE was increased in the outer molecular layer of the ipsilateral dentate gyrus from 8 to $30 \mathrm{DPL}$. In contrast, the activity of ChAT, the enzyme responsible for the synthesis of $\mathrm{ACh}$, and the densities of specific binding sites for ${ }^{3} \mathrm{H}-\mathrm{AH} 5183 /$ vesamicol (blocker of the $\mathrm{ACh}$ vesicular transport sites), ${ }^{3} \mathrm{H}$ hemicholinium-3 (blocker of the high-affinity choline uptake sites), muscarinic- $\mathrm{M}_{2}$ ( ${ }^{3} \mathrm{H}-\mathrm{AF}-\mathrm{DX} 384$ and ${ }^{3} \mathrm{H}-\mathrm{ACC}$ ), muscarinic-M ${ }_{1}{ }^{3} \mathrm{H}$-pirenzepine), and nicotinic $\left({ }^{3} \mathrm{H}-\mathrm{N}\right.$-methylcarbamylcholine) cholinergic receptors were not increased on the ipsilateral molecular layer of the dentate gyrus, as compared to their contralateral controls. We conclude that the increase In AChE staining in the molecular layer of the dentate gyrus following entorhinal cortex lesions may be due to changes in noncholinergic neurons.
\end{abstract}

[Key words: entorhinal cortex lesions, hippocampus, dentate gyrus, muscarinic receptors, nicotinic receptors, highaffinity choline uptake, vesamicol, AChE, sprouting, cholinergic system]

More than ninety years ago, Ramón y Cajal (1901) described an important projcction from the entorhinal cortex to the hippocampal formation. This neural system arises from layers II and III of the entorhinal cortex and provides major inputs to

\footnotetext{
Received June 3, 1993; revised Oct. 4, 1993; accepted Oct. 14, 1993.

We thank Dr. Paul Clarke for his helpful comments and critical reading of the manuscript. Annie Baccichet and Doris Dea are acknowledged for their technical support in performing lesions of the entorhinal cortex. This work was supported by grants from the Medical Research Council of Canada (R.Q., J.P.). R.Q. and J.P. are, respectively, holders of "Chercheur-Boursier" of the "Fonds de la Recherche en Santé du Québec" (FRSQ) and an MRCC scholarship. I.A. is the holder of a studentship from the Alzheimer Society of Canada.

Correspondence should be addressed to Rémi Quirion, Ph.D., Douglas Hospital Research Center, 6875 Lasalle Boulevard, Verdun, Quebec, Canada H4H 1 R3. Copyright (c) 1994 Society for Neuroscience $0270-6474 / 94 / 142476-09 \$ 05.00 / 0$
}

the dentate granule cells and to the pyramidal neurons of the hippocampal formation (Steward and Scoville, 1976). Lesions of this pathway in rodents have become, over the years, a favored model system to study adaptive changes in the CNS. Following entorhinal cortex lesions (ECL), synaptic endings derived from intact fibers in close proximity to the denervated molecular layer of the dentate gyrus grow toward the newly exposed postsynaptic structures. It has been proposed that the sprouting fibers and resulting synapses originate from cholinergic septal neurons (Lynch et al., 1972), glutamatergic commissural-associational pyramidal cells of the $\mathrm{CA} 3$ /hilus areas (Lynch et al., 1976; Scheff et al., 1980; Geddes et al., 1985), and, to a lesser extent, neurons of the contralateral entorhinal cortex (Steward et al., 1974). The remarkable ability of the dentate gyrus to remodel its circuitry is evident during development and remains in adulthood (Lynch et al., 1972; Cotman et al., 1973; Nadler et al., 1973, 1977; Storm-Mathisen, 1974; Scheff et al., 1980; Hoff et al., 1981; Stanfield and Cowan, 1982).

Marked increases in acetylcholinesterase (AChE) staining or activity in the molecular layer of the dentate gyrus have been observed following disruption of the perforant path (entorhinodentate fibers) (Lynch et al., 1972; Cotman et al., 1973; StormMathisen, 1974; Scheff et al., 1980; Stanfield and Cowan, 1982). It was first suggested that the induced increase in AChE staining or activity, following ECL or transection of the perforant path, relies on the integrity of the cholinergic septohippocampal projections, since transection of the fimbria-fornix severely impaired this $\mathrm{AChE}$ response (Lynch et al., 1972; Storm-Mathisen, 1974).

Interestingly, a very similar reorganization of dentate synaptic inputs was described in patients suffering from Alzheimer's disease (AD). This neuropathology is characterized by a severe loss of neurons present in layers II and III of the entorhinal cortex (Hyman et al., 1987). Although some studies have reported a clear decrease in $\mathrm{AChE}$ activity or $\mathrm{AChE}$ staining in hippocampi of AD patients (Davies, 1979; Henke and Lang, 1983), others have observed enhanced AChE staining in the neuropil of some $\mathrm{AD}$ patients, especially in the outer two-thirds of the molecular layer of the dentate gyrus (Geddes et al., 1985; Hyman et al., 1987; Senut et al., 1991), a profile similar to that seen following $\mathrm{ECL}$ in the rat brain. Increases in AChE staining in the hippocampi of $\mathrm{AD}$ patients have been interpreted as evidence for a compensatory sprouting of septohippocampal cholinergic neurons. However, Ransmayr et al. (1989) measured significant reductions in choline acetyltransferase (ChAT)-like immunoreactivity in the molecular layer of the dentate gyrus of AD patients, in accordance with previously reported decrements of 
ChAT activity in the whole hippocampal formation (Reisine et al., 1978; Davies, 1979; Perry et al., 1986; Araujo et al., 1988a; Rinne et al., 1989; Aubert et al., 1992a). It is difficult to explain these apparent inconsistencies but it may be that, as already suggested (Levey et al., 1983, 1984; Small, 1989; Greenfield, 1991; Mesulam and Geula, 1991), AChE-positive fibers are not exclusive to cholinergic neurons.

Similar discrepancies were also observed in the dentate gyrus of the rat brain. For example, it has been shown that selective lesions of the granule cells of the dentate gyrus, mimicking ECL, induced the expected increase in AChE staining in the outer two-thirds of the molecular layer (McKeon et al., 1989). However, this response occurs even in the absence of septal inputs (removed by fimbria-fornix lesions) (McKeon et al., 1989). Following these manipulations, ChAT-like immunoreactivity remains unchanged in the hippocampus, whereas increases in $\mathrm{AChE}$ staining were evident (McKeon et al., 1989). It is also of interest that the density of the total population of muscarinic receptors, labeled with ${ }^{3} \mathrm{H}$-quinuclidinyl benzilate, did not parallel the increase in AChE staining seen following ECL in the rat brain (Monaghan et al., 1982).

Taken together, these data bring doubts about the cholinergic nature of the sprouting observed in the dentate gyrus following ECL. Therefore, in the present study, we systematically examined key neurochemical markers of hippocampal cholinergic neurotransmission in adult ECL rats. First, the extent of the sprouting was confirmed using AChE staining (Karnovsky and Roots, 1964). Subsequently, the capacity of the newly formed innervation to synthesize acetylcholine (ACh) was evaluated using ChAT activity (Fonnum, 1969; Tucek, 1978), a well-established presynaptic cholinergic marker. We also investigated the integrity of various other pre- and postsynaptic components of the cholinergic synapse using quantitative receptor autoradiography. ${ }^{3} \mathrm{H}$-hemicholinium-3 and ${ }^{3} \mathrm{H}-\mathrm{AH} 5183 /$ vesamicol, which respectively labeled high-affinity choline uptake carrier sites (Rainbow et al., 1984; Quirion, 1985, 1987; Vickroy et al., 1985) and ACh vesicular transport sites (Marien et al., 1987; Parsons et al., 1987; Altar and Marien, 1988; Diebler and Morot Gaudry-Talarmain, 1989), were used as presynaptic markers. As putative presynaptic autoreceptors (Raiteri et al., 1984; Mash et al., 1985; Lapchak et al., 1989; Weiler, 1989), the labeling profile of the muscarinic- $\mathrm{M}_{2}$ receptors was studied using both ${ }^{3} \mathrm{H}-\mathrm{ACh}$ (Kcllar et al., 1985; Quirion and Boksa, 1986; Schwartz, 1986; Quirion et al., 1989) and ${ }^{3}$ H-AF-DX 384 (Entzeroth and Mayer, 1990; Miller et al., 1991; Aubert et al., 1992b), while ${ }^{3} \mathrm{H}-\mathrm{N}$-methylcarbamylcholine ( ${ }^{3} \mathrm{H}$-MCC) was used as a marker of putative nicotinic autoreceptors (Abood and Grassi, 1986; Boksa and Quirion, 1987; Yamada et al., 1987; Araujo et al., 1988 b, 1989). Postsynaptic muscarinic- $M_{1}$ receptor sites were labeled with ${ }^{3} \mathrm{H}$-pirenzepine (Watson et al., 1982, 1984; Spencer et al., 1986; Quirion et al., 1989). The results failed to demonstrate the cholinergic nature of the AChE sprouting observed in the dentate gyrus following ECL.

\section{Materials and Methods}

Animals and chemicals. Male Fisher-344 rats (250-300 gm) were obtained from Charles Kiver Breeding Farms (St-Constant, Quebec, Canada). ${ }^{3} \mathrm{H}$-pirenzepine (70.4-87.0 Ci/mmol), ${ }^{3} \mathrm{H}-\mathrm{AF}-\mathrm{DX} 384$ (87.4-100.8 $\mathrm{Ci} / \mathrm{mmol}),{ }^{3} \mathrm{H}$-choline $(85 \mathrm{Ci} / \mathrm{mmol}),{ }^{3} \mathrm{H}$-hemicholinium-3 $(142 \mathrm{Ci} /$ $\mathrm{mmol}),{ }^{3} \mathrm{H}-\mathrm{N}$-methylcarbamylcholine $(84.0 \mathrm{Ci} / \mathrm{mmol}),{ }^{3} \mathrm{H}$-AH5183 $(48.0$ $\mathrm{Ci} / \mathrm{mmol})$, and ${ }^{14} \mathrm{C}$-acetyl coenzyme $\mathrm{A}(48.8 \mathrm{mCi} / \mathrm{mmol})$ were purchased from New England Nuclear (Boston, MA). Nicotine (free hase), atropine sulfate, hemicholinium-3, choline chloride, and eserine hemisulfate were bought from Sigma Chemical Co. (St. Louis, MO). Acetylcholine chloride was supplied by Hoffmann La Roche (Basel, Switzerland). Unlabeled acetyl coenzyme A was purchased from Boehringer Mannheim (Mannheim, Germany). Tetraphenylboron (sodium salt) and 3-heptanone were from Aldrich Chemical Co. (Milwaukee, WI). Ethyl acetate was bought from American Chemicals Co. (Montreal, Quebec, Canada). Bovine serum albumin ( $98 \%$ fatty acid free) and Ecolite scintillation cocktail were purchased from ICN Biochemicals (Irvine, CA). Triton $\mathrm{X}-100(100 \%)$ scintillation grade was from Amersham (Arlington, IL). ${ }^{3} \mathrm{H}$-Hyperfilm and ${ }^{3} \mathrm{H}$-standards were purchased from Amersham (Oakville, Ontario, Canada). Developer (D-19) and fixer (Rapid Fixer) used for ${ }^{3} \mathrm{H}$-Hyperfilm processing were from Kodak Chemical Inc. (Montreal, Quebec, Canada). Unlabeled AH5183/vesamicol was provided as a gift by Dr. S. M. Parsons (University of California, Santa Barbara, CA). All other chemicals were from Fisher Scientific (Montreal, Quebec, Canada).

Entorhinal cortex lesions. Adult F344 male rats received multiple electrolytic lesions $(30 \mathrm{sec})$ of the entorhinal cortex area, unilaterally, at three different depths $(2,4$, and $6 \mathrm{~mm}$ below dura $)$, in three locations (L:3.3, B:0; L:4.3, B:0; L:5.1, B: $-1 \mathrm{~mm}$ ) as described in detail elsewhere (Scheff et al., 1980; Poirier and Nichols, 1991). At various days postlesion (DPL), rats were killed and their brains were rapidly removed from the skull, immersed in 2-methylbutane at $-40^{\circ} \mathrm{C}$ for several seconds, and then stored at $-80^{\circ} \mathrm{C}$ until use. Time course analysis includes controls (unoperated) and 2, 4, 8,14, and 30 DPL animals.

$A C h E$ histochemistry. The internal remodeling of the dentate gyrus following ECL was confirmed by AChE staining as adapted from Karnovsky and Roots (1964). Slides used for ${ }^{3} \mathrm{H}-\mathrm{N}$-methylcarbamylcholine nicotinic receptor autoradiography were next processed for AChE staining. Briefly, they were incubated in a solution containing $2 \mathrm{mg} / \mathrm{ml} \mathrm{ACh}$ iodide, 13 parts of $\mathrm{NaH}_{2} \mathrm{PO}_{4}(\mathrm{O} .1 \mathrm{M}), 1$ part of Na-citrate $(0.3 \mathrm{M}), 2$ parts of $\mathrm{CuSO}_{4}(30 \mathrm{~mm}), 2$ parts of distilled water, and 2 parts of $\mathrm{K}$-ferricyanide $(5 \mathrm{~mm})$ for $5 \mathrm{hr}$ at room temperature. Slides were then dehydrated and mounted for microscopic examination.

Autoradiographic visualization of various cholinergic markers. Coronal frozen sections $\left(15 \mu \mathrm{m}\right.$ thick) were cut at $-18^{\circ} \mathrm{C}$, thaw mounted on poly-L-lysine-coated slides (two sections per slide), air dried overnight, and then stored at $-80^{\circ} \mathrm{C}$ until use. Four to 10 animals were used for each point of the time course (control, 2, 4, 8, 14, and $30 \mathrm{DPL}$ ).

${ }^{3} \mathrm{H}$-N-methylcarbamylcholine/nicotinic receptors. Sections were first equilibrated at $4^{\circ} \mathrm{C}$ and then incubated for $1 \mathrm{hr}\left(4^{\circ} \mathrm{C}\right)$ in Tris $\mathrm{HCl}$ buffer ( $\mathrm{pH} 7.4$ ) of the following composition (in mM): Tris, $50 ; \mathrm{NaCl}, 120$; $\mathrm{KCl}, 5 ; \mathrm{CaCl}_{2}, 2 ; \mathrm{MgCl}_{2}, 1$; containing $20 \mathrm{nM}{ }^{3} \mathrm{H}-\mathrm{MCC}$ with or without nicotine $(10 \mu \mathrm{M})$ to determine specific binding. Slides were transferred sequentially through four washes of $2 \mathrm{~min}$ each in Tris $(50 \mathrm{~mm}) \mathrm{HCl}$ buffer $(\mathrm{pH} 7.4)$ at $4^{\circ} \mathrm{C}$ before being rapidly dipped in cold deionized water. Sections were dried and apposed to films for 7 months. Films were then developed as described before (Quirion et al., 1981). Specifically bound ${ }^{3} \mathrm{H}-\mathrm{MCC}$, in layers of the dentate gyrus and $\mathrm{CA} 1$ region of the Ammon's horn of the hippocampus, was quantified using ${ }^{3} \mathrm{H}$ labeled standards and computerized image analysis (MCID System, Image Research Inc., St. Catharines, Ontario, Canada). For each section, six target fields were taken throughout each lamina of the hippocampus. The variation between target fields was $15 \%$ maximum. For each animal, sections were in duplicate. Under these conditions, specifically bound ${ }^{3} \mathrm{H}-\mathrm{MCC}$ represented $40-60 \%$ of bound ligand (Araujo et al., 1989).

${ }^{3} \mathrm{H}$-hemicholinium-3/high-affinity choline uptake sites. Sections were first equilibrated at $4^{\circ} \mathrm{C}$ and then incubated for $1 \mathrm{hr}$ at $4^{\circ} \mathrm{C}$ in Tris (50 $\mathrm{mm})-\mathrm{NaCl}(300 \mathrm{~mm}) \mathrm{HCl}$ buffer (pH 7.4) containing $15 \mathrm{~nm}{ }^{3} \mathrm{H}-$ hemicholinium-3 in the presence or absence of unlabeled hemicholinium-3 $(20 \mu \mathrm{M})$ to determine specific binding. At the end of the incubation, slides were transferred sequentially through six washes of 2 min each in Tris $(50 \mathrm{~mm}) \mathrm{HCl}$ buffer $\left(\mathrm{pH} \mathrm{7.4)}\right.$ at $4^{\circ} \mathrm{C}$ before being rapidly dipped in cold distilled water to remove ions. Sections were dried and apposed to films for 3 weeks. Films were then developed and analyzed as described for ${ }^{3} \mathrm{H}-\mathrm{MCC}$. Under these conditions, specifically bound ${ }^{3} \mathrm{H}$-hemicholinium-3 represented $80-85 \%$ of totally bound ligand (Quirion, 1987).

${ }^{3} \mathrm{H}$-AH5183 (vesamicol)/ACh vesicular transport sites. Sections were brought to room temperature and preincubated for $30 \mathrm{~min}$ in Tris $\mathrm{HCl}$ buffer of the following composition (in mM): Tris, 50; $\mathrm{NaCl}, 120 ; \mathrm{KCl}$, 5; $\mathrm{CaCl}_{2}, 2 ; \mathrm{MgCl}_{2}, 1\left(\mathrm{pH} \mathrm{7.4)}\right.$ at $22^{\circ} \mathrm{C}$; before being incubated for $1 \mathrm{hr}$ in fresh buffer containing $15 \mathrm{nM}{ }^{3} \mathrm{H}-\mathrm{AH} 5183$ in the absence or presence of unlabeled AH5183 (1 $\mu \mathrm{M})$ to determine specific binding. Sections were then transferred sequentially through four washes of $30 \mathrm{sec}$ each 


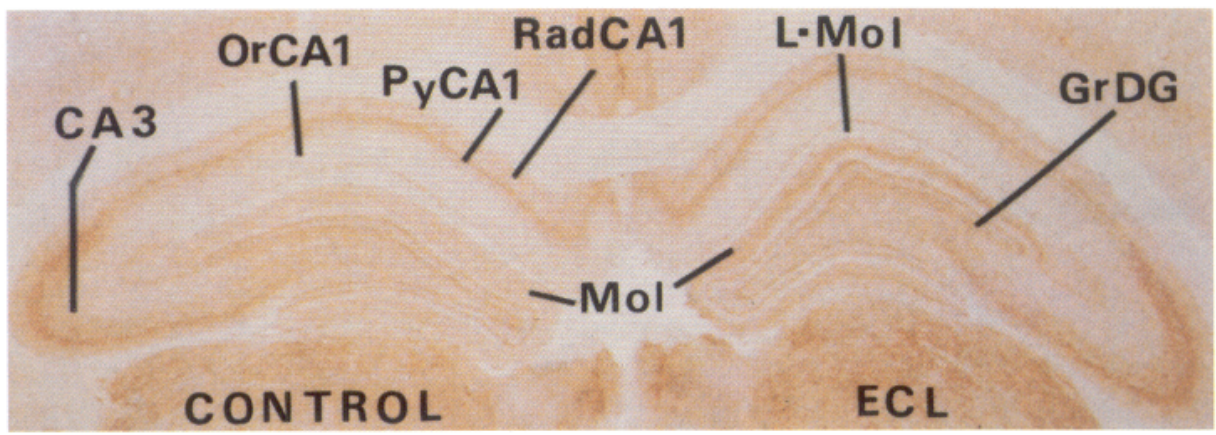

Figure 1. Typical photomicrograph of AChE staining in the hippocampus at $30 \mathrm{DPL}$. The control and lesioned $(E C L)$ sides are illustrated. Anatomical identification is based on the Paxinos and Watson (1982) atlas. CA3, fields CA3 of Ammon's horn of the hippocampus; GrDG, granular layer of the dentate gyrus; $L-\mathrm{Mol}$, lacunosum-moleculare layer of the hippocampus; $\mathrm{Mol}$, molecular layer of the dentate gyrus; $\mathrm{OrCA1}$, oriens layer in CA1 field of Ammon's horn of the hippocampus; PyCA1, pyramidal layer in CA1 field of Ammon's horn of the hippocampus; RadCA1, stratum radiatum layer in CAl field of Ammon's horn of the hippocampus. A similar increase in AChE staining in the molecular layer of the dentate gyrus on the lesion side is also seen at 8 DPL (see Fig. 2) and 14 DPL.

in Tris ( $50 \mathrm{~mm}) \mathrm{HCl}$ buffer $(\mathrm{pH} 7.4)$ at $4^{\circ} \mathrm{C}$ followed by a quick dip in cold deionized water. Sections were dried and apposed to films for 3 weeks. Films were then developed and analyzed as described for ${ }^{3} \mathrm{H}-$ MCC. Under these conditions, specifically bound ${ }^{3} \mathrm{H}-\mathrm{AH} 5183$ represented between $90 \%$ and $95 \%$ of bound ligand (Marien et al., 1987).

${ }^{3} \mathrm{H}$-ACh/muscarinic- $\mathrm{M}_{2}$ receptors. ${ }^{3} \mathrm{H}$-choline was acetylated on the day of the experiment, as described in detail elsewhere (Quirion and Boksa, 1986). Only preparations showing $95 \%$ and higher degrees of acetylation were used as radioligands. Sections were equilibrated at $4^{\circ} \mathrm{C}$; preincubated for $10 \mathrm{~min}$ in Tris $\mathrm{HCl}$ buffer of the following composition (in mM): Tris, $50 ; \mathrm{NaCl}, 120 ; \mathrm{KCl}, 5 ; \mathrm{CaCl}_{2}, 2 ; \mathrm{MgCl}_{2}, 1$; diisopropylfluorophosphate, 0.1 ; nicotine, $0.02(\mathrm{pH} \mathrm{7.4)}$; and incubated for $1 \mathrm{hr}$ at $4^{\circ} \mathrm{C}$ in fresh buffer containing $20 \mathrm{~nm}{ }^{3} \mathrm{H}-\mathrm{ACh}$, with or without atropine $(1 \mu \mathrm{M})$ to determine specific binding. Slides were then transferred in two subsequent washes of 5 min each in Tris $(50 \mathrm{~mm}) \mathrm{HCl}$ buffer $(\mathrm{pH} 7.4)$ at $4^{\circ} \mathrm{C}$ followed by a rapid dip into cold distilled water. Sections were dried and apposed to films for 1 month. Films were then developed and analyzed as described for ${ }^{3} \mathrm{H}-\mathrm{MCC}$. Under those assay conditions, specifically bound ${ }^{3} \mathrm{H}-\mathrm{ACh}$ represented $90-95 \%$ of bound ligand and possessed a muscarinic $\mathbf{M}_{2}$-like profile (Quirion et al., 1989).

${ }^{3} H$-AF-DX $384 /$ muscarinic- $M_{2}$ and ${ }^{3} H$-pirenzepine/muscarinic- $M$, receptors. For both radioligands, a similar protocol was followed as reported previously (Quirion and Boksa, 1986; Quirion et al., 1989; Aubert et al., 1992b). Sections were equilibrated at room temperature $\left(22^{\circ} \mathrm{C}\right)$; preincubated for $15 \mathrm{~min}\left(22^{\circ} \mathrm{C}\right)$ in Krebs buffer of the following composition (in mM): $\mathrm{NaCl}, 120 ; \mathrm{MgSO}_{4}, 1.2 ; \mathrm{KH}_{2} \mathrm{PO}_{4}, 1.2$; glucose, $5.6 ; \mathrm{NaHCO}_{3}, 25 ; \mathrm{CaCl}_{2}, 2.5 ; \mathrm{KCl}, 4.7$ (pH 7.4); and then incubated at $22^{\circ} \mathrm{C}$ for $1 \mathrm{hr}$ in fresh buffer containing either $15 \mathrm{nM}^{3} \mathrm{H}$-pirenzepine or $2 \mathrm{~nm}{ }^{3} \mathrm{H}$-AF-DX 384 , with or without atropine $(1 \mu \mathrm{M})$ to determine specific binding. Slides were then transferred sequentially through three rinses ( 4 min each) in Tris $(50 \mathrm{~mm}) \mathrm{HCl}$ buffer $(\mathrm{pH} \mathrm{7.4})$ at $4^{\circ} \mathrm{C}$, followed by a rapid dip in cold distilled water. Sections were next dried under a stream of cold air and tightly juxtaposed to films for $15 \mathrm{~d}$. Films were then developed and layers of the dentate gyrus, CA1, and CA 3 regions of the Ammon's horn of the hippocampus were analyzed as described for ${ }^{3} \mathrm{H}-\mathrm{MCC}$. Under these conditions specifically bound ${ }^{3} \mathrm{H}-$ pirenzepine and ${ }^{3} \mathrm{H}-\mathrm{AF}-\mathrm{DX} 384$ represented at least $90-95 \%$ of bound ligands.

ChAT activity. To determine ChAT activity, dissected ipsilateral hippocampi were homogenized and incubated for $15 \mathrm{~min}$ in buffer containing ${ }^{14} \mathrm{C}$-acetyl coenzyme $\mathrm{A}$ as previously described in detail elsewhere (Araujo et al., 1988a) using the method of Fonnum (1969), as modified by Tuček (1978). Three animals were used for each point of the time course (control, 2, 8, and 30 DPL).

Protein content. Protein content of samples used for ChAT activity was determined by the method of Lowry et al. (1951), using bovine serum albumin as standard.

Data analysis. Paired $t$ test analysis was used in order to compare the lesion side of each animal with the control side at each given point of the time course. Results were considered significant if $P<0.01$. ANOVA followed by Newman-Keuls analysis was used to evaluate the effect of the time course on binding parameters in lesioned animals on both lesioned and control sides as compared to control (unoperated) animals.

\section{Results}

\section{AChE histochemistry}

As reported before by several groups (see introductory remarks), AChE staining is clearly increased in the outer two-thirds of the molecular layer of the dentate gyrus, ipsilaterally to the ECL, from 8 to 30 DPL (Figs. 1, 2).

\section{${ }^{3} \mathrm{H}-\mathrm{MCC} /$ nicotinic receptors}

Nicotinic receptor binding sites, labeled with ${ }^{3} \mathrm{H}-\mathrm{MCC}$, were significantly (paired $t$ test, $P<0.01$ ) decreased in the molecular layer of the dentate gyrus at 8 and 30 DPL (Figs. 2, 3). However, no significant differences were observed in the CA1 region of the hippocampus at any DPL (Fig. 2).

\section{${ }^{3}$ H-hemicholinium-3/high-affinity choline uptake sites}

The apparent density of high-affinity choline uptake binding sites, as measured with ${ }^{3} \mathrm{H}$-hemicholinium-3, was unchanged in the molecular layer of the dentate gyrus at any DPL (Figs. 2, 4). The granular layer of the dentate gyrus and the oriens, pyramidal, and radiatum laminae of the CA1 region of the hippocampus as well as the lacunosum-moleculare layer were also unaltered following ECL (Fig. 2).

\section{${ }^{3} \mathrm{H}$-AH5183 (vesamicol)/ACh vesicular transport sites}

The apparent density of ${ }^{3} \mathrm{H}-\mathrm{AH} 5183 /$ vesamicol binding, the blocker of $\mathrm{ACh}$ vesicular transport sites, was unchanged in the ipsilateral molecular layer of the dentate gyrus following ECL as compared to the contralateral side (Figs. 2, 4). No differences in ${ }^{3} \mathrm{H}$-AH5183 binding were found in the granular layer of the dentate gyrus and other regions of the hippocampus such as the oriens, pyramidal, and radiatum layers of the CAl region and the lacunosum-moleculare layer (Fig. 2). However, a transient but significant bilateral increase $(25-30 \%)$ in binding was observed at 2 DPL in the molecular layer of the dentate gyrus when compared to control (unoperated animals) (Fig. 4). This significant bilateral increase at 2 DPL was also observed in the granular layer of the dentate gyrus and in different layers of the CAl region and the lacunosum-moleculare layer of the hippocampus (results not shown).

\section{${ }^{3} \mathrm{H}$-ACh/muscarinic- $\mathrm{M}_{2}$ receptors}

The apparent density of ${ }^{3} \mathrm{H}-\mathrm{ACh}$ putative muscarinic- $\mathrm{M}_{2}$ receptor binding sites was not significantly altered in the lesioned 


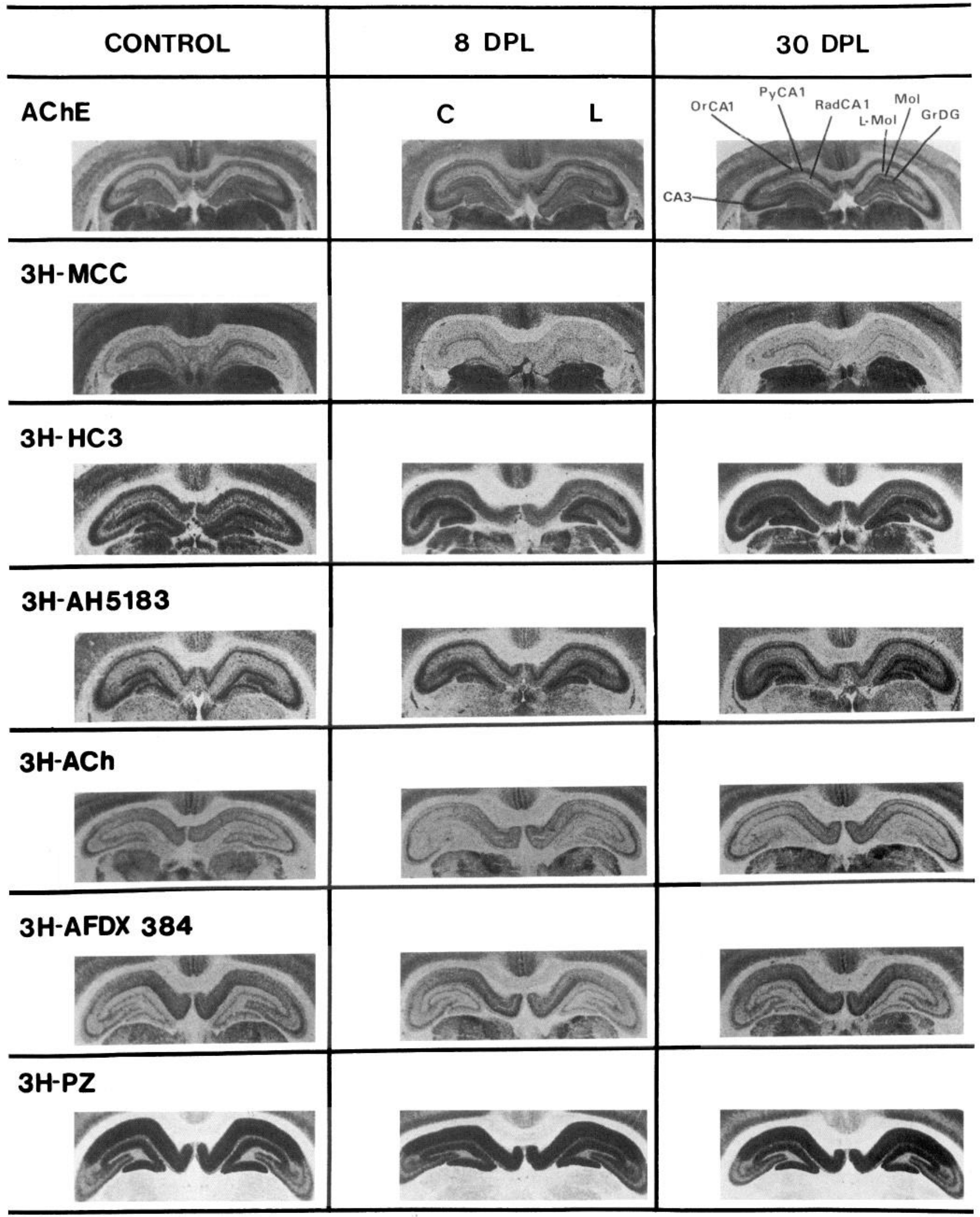

Figure 2. Typical photomicrographs of AChE staining $(A C h E),{ }^{3} \mathrm{H}-\mathrm{MCC} /$ nicotinic receptor $(3 H-M C C),{ }^{3} \mathrm{H}$-hemicholinium-3/high-affinity choline uptake site $(3 H-H C 3),{ }^{3} \mathrm{H}-\mathrm{AH} 5183$-vesamicol/ACh vesicular transport site $(3 \mathrm{H}$ - $\mathrm{AH} 5183),{ }^{3} \mathrm{H}-\mathrm{ACh} / \mathrm{muscarinic}-\mathrm{M}_{2}$ receptor $(3 \mathrm{H}$ - $\mathrm{ACh}),{ }^{3} \mathrm{H}-\mathrm{AF}-\mathrm{DX}$ $384 /$ muscarinic- $\mathrm{M}_{2}$ receptor $(3 H-A F D X 384)$, and ${ }^{3} \mathrm{H}$-pirenzepine/muscarinic- $\mathrm{M}_{1}$ receptor $(3 H-P Z)$ autoradiography in coronal sections of the rat hippocampus in control and 8 and 30 DPL (see Fig. 1 for abbreviations). The control $(C)$ and lesioned $(L)$ sides are illustrated on the left and right, respectively, at 8 and 30 DPL. 

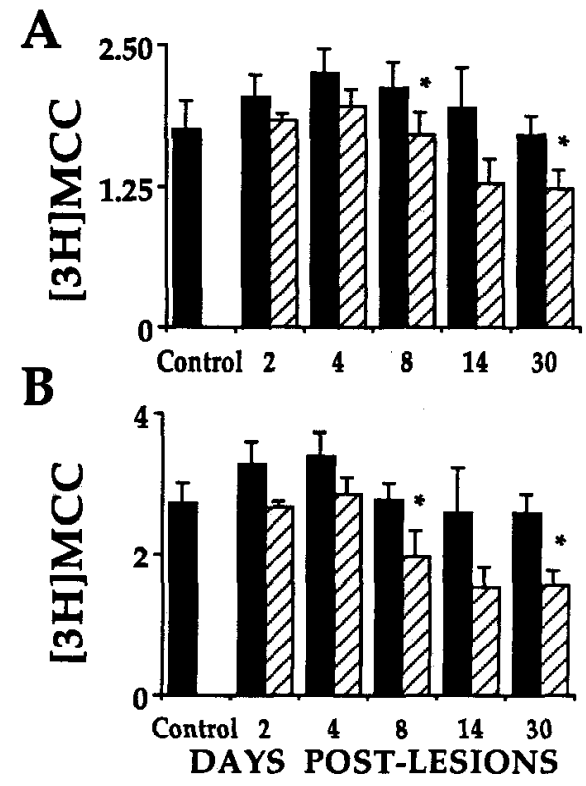

Figure 3. Quantitative analysis of ${ }^{3} \mathrm{H}-\mathrm{MCC} /$ nicotinic receptors in the molecular layer of the dentate gyrus. Film autoradiograms (Fig. 2) were analyzed using computerized densitometry. Results are expressed in $\mathrm{fmol} / \mathrm{mg}$ wet tissue weight and represent the mean \pm SEM of 4-10 animals for each DPL (control, $2,4,8,14,30$ ). Solid and hatched bars represent, respectively, control and lesioned sides. In $A$ and $B$, the outer third and middle third, respectively, of the molecular layer were quantified. ${ }^{*}$ denotes that significant differences were found between the control and lesioned sides at a given DPL if $P<0.01$ using paired $t$ test analysis.

as compared to contralateral sides (paired $t$ test analysis), at any DPL, in the dentate gyrus (Figs. 2, 4). However, a significant increase $(28 \%)$ was detected, using ANOVA analysis, in the molecular layer at $30 \mathrm{DPL}$ on the lesioned side as compared to the controls (unoperated animals) (Fig. 4). No significant differences in ${ }^{3} \mathrm{H}$-ACh binding were observed in any layers of the CAl region of the hippocampus (Fig. 2).

\section{${ }^{3} \mathrm{H}-\mathrm{AF}-\mathrm{DX} 384 /$ muscarinic- $\mathrm{M}_{2}$ receptors}

Muscarinic- $\mathrm{M}_{2}$ receptor binding, as measured with ${ }^{3} \mathrm{H}-\mathrm{AF}-\mathrm{DX}$ 384, was unchanged in the dentate gyrus at any DPL (Figs. 2, 4). Similarly, ${ }^{3} \mathrm{H}-\mathrm{AF}-\mathrm{DX} 384$ binding sites in the oriens, pyramidal, and radiatum laminae of the $C A 1$ and $C A 3$ regions of the hippocampus were unaltered at any DPL (Fig. 2).

\section{${ }^{3} H$-pirenzepine/muscarinic- $M$, receptors}

Muscarinic- $\mathbf{M}_{1}$ receptor binding was unaltered in the dentate gyrus at any DPL (Figs. 2, 4). In addition, no differences in ${ }^{3} \mathrm{H}$ pirenzepine binding were observed in any layers of the $\mathrm{CA} 1$ and $\mathrm{CA} 3$ regions of the hippocampus (Fig. 2). However, a significant (paired $t$ test, $p<0.01$ ) increase (30\%) in muscarinic $\mathrm{M}_{t}$ binding sites in the ipsilateral lacunosum-moleculare layer of the hippocampus was detected at 30 DPL (Fig. 2).

\section{ChAT activily}

ChAT activity was measured in the entire ipsilateral hippocampus and remained unchanged (values ranging between 51 and $63 \mathrm{nmol}$ of ACh formed $/ \mathrm{mg}$ protein/hr) throughout the whole period following ECL $(2,8,30 \mathrm{DPL})$ as compared to control animals (Fig. 5).
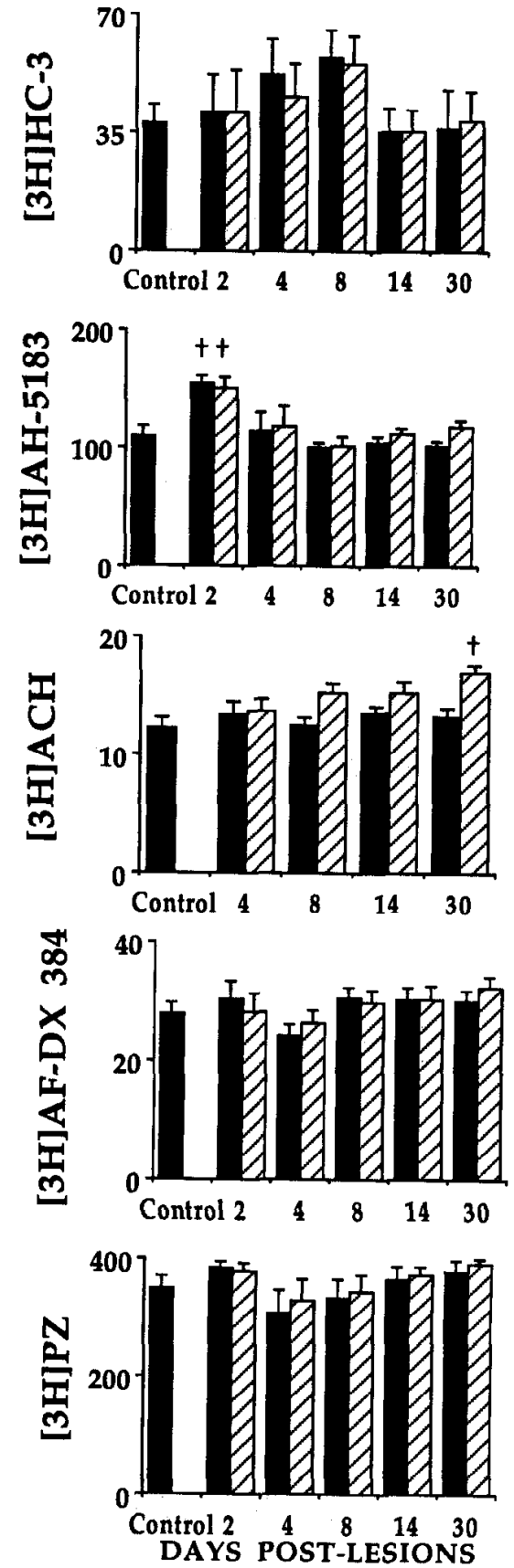

Figure 4. Quantitative analysis of ${ }^{3} \mathrm{H}$-hemicholinium-3/high-affinity choline uptake sites ([3IIJHC-3), ${ }^{3} \mathrm{H}$-AH5183-vesamicol/ACh vesicular transport sites $\left([3 H J A H-5183),{ }^{3} \mathrm{H}-\mathrm{ACh} /\right.$ muscarinic- $\mathrm{M}_{2}$ receptors $([3 H] A C H),{ }^{3} \mathrm{H}-\mathrm{AF}-\mathrm{DX} 384 /$ muscarinic-M $_{2}$ receptors $([3 H] A F-D X 384)$, and ${ }^{3} \mathrm{H}$-pirenzepine/muscarinic- $\mathrm{M}_{1}$ receptors $([3 H] P Z)$ in the molecular layer of the dentate gyrus. Film autoradiograms (Fig. 2) were analyzed using computerized densitometry. Results are expressed in $\mathrm{fmol} / \mathrm{mg}$ wet tissue weight and represent the mean \pm SEM of 4-10 animals for each DPL (control, 2, 4, 8, 14, 30). Solid and hatched bars represent, respectively, control and lesioned sides. $\dagger$ denotes that significant differences, using ANOVA/Newman-Keuls analysis, were found between the control or lesioned side at a particular DPL as compared to the controls (unoperated animals represented by the first, single, solid column labeled Control).

\section{Discussion}

For the past 20 years, intensification of $\mathrm{AChE}$ staining or activity in the outer two-thirds of the molecular layer of the dentate gyrus following ECL has been considered to be a valid dem- 
onstration of compensatory cholinergic sprouting in response to deafferentation (see, e.g., Lynch et al., 1972; Nadler et al., 1977; Amaral et al., 1980; Scheff et al., 1980; Fagan and Gage, 1990). It has generally been assumed that alterations in AChE staining or activity are caused by the proliferation of septohippocampal fiber terminals (see introductory renlarks). The close relationship between septohippocampal terminals and $\mathrm{AChE}$ staining is best exemplified by a marked loss of AChE staining in the molecular layer of the dentate gyrus following transection of the fimbria-fornix in normal and ECL animals (Shute and Lewis, 1963; Lynch et al., 1972; Storm-Mathisen, 1974). However, discrepancies have been reported between AChE staining, ChAT-like immunoreactivity, and tracing of the septohippocampal pathway (Lynch et al., 1978; Stanfield and Cowan, 1982; Baisden et al., 1984; Wainer et al., 1985). These apparent mismatches have been explained by the presence of both cholinergic and noncholinergic septohippocampal or intrinsic projections (Baisden et al., 1984; Wainer et al., 1985), as well as the likely existence of nonseptal cholinergic projections from the supramamillary region (Lasher et al., 1980) and noncholinergic, AChEpositive intrinsic hippocampal innervation (McKeon et al., 1989). Although electron microscopy studies have clearly shown that reactive synaptogenesis occurs in the deafferented zones in which $\mathrm{AChE}$ activity increases (Matthews et al., 1976a,b), there has been no direct evidence that septal cholinergic projections participate in this response by increasing the number of functional synaptic contacts.

Accordingly, the neurochemical status of the putative cholinergic sprouting was studied using multiple pre- and postsynaptic markers of cholinergic synapses. These failed to show any relationships with the altered hippocampal AChE staining seen post-ECL. Two well-established presynaptic markers, ChAT activity and ${ }^{3} \mathrm{H}$-hemicholinium-3 binding to the high-affinity choline uptake sites (Rainbow et al., 1984; Quirion, 1985, 1987; Vickroy et al., 1985), were unaltered in the hippocampal formation at any time postlesions; this was in marked contrast with the increase in AChE staining in the molecular layer of the dentate gyrus. Other putative presynaptic markers of the hippocampal cholinergic synapse such as ${ }^{3} \mathrm{H}-\mathrm{AH} 5183$, a blocker of ACh vesicular storage (Marien et al., 1987; Parsons et al., 1987; Altar and Marien, 1988; Diebler and Morot Gaudry-Talarmain, 1989), and muscarinic- $M_{2}$ (Raiteri et al., 1984; Kellar et al., 1985; Mash et al., 1985; Quirion and Boksa, 1986; Schwartz, 1986; Lapchak et al., 1989; Quirion et al., 1989; Weiler, 1989; Entzeroth and Mayer, 1990; Miller et al., 1991; Aubert et al., 1992b) and nicotinic (Abood and Grassi, 1986; Boksa and Quirion, 1987; Yamada et al., 1987; Araujo et al., 1988b, 1989) receptors also failed to be increased as the AChE staining following ECL. In contrast, the significant decrease in ${ }^{3} \mathrm{H}-\mathrm{MCC} /$ nicotinic binding in the ipsilateral dentate gyrus at 8 and 30 DPL could be duc to the localization of a certain proportion of nicotinic receptors on terminals of the perforant path. Up to now, there is no direct evidence for localization of nicotinic receptors on the terminals of the perforant path. However, Swanson et al. (1987) suggested such a localization in the dentate gyrus using a monoclonal antibody against neuronal nicotinic receptors. Interestingly, the distribution of this monoclonal antibody in the hippocampus (Swanson et al., 1987) is very similar to the labeling pattern of ${ }^{3} \mathrm{H}$-ligands for neuronal nicotinic receptors such as ${ }^{3} \mathrm{H}-\mathrm{MCC}$ (Boksa and Quirion, 1987; Yamada et al., 1987; Araujo et al., 1989; present results) and ${ }^{3} \mathrm{H}$-nicotine or ${ }^{3} \mathrm{H}$-ACh (Clarke et al., 1985; Schwartz, 1986). A localization

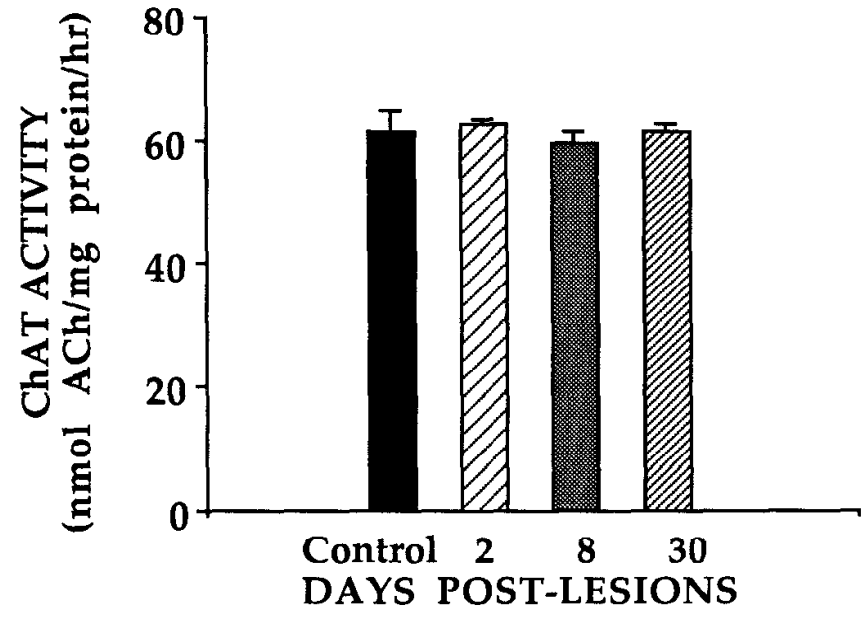

Figure 5. Evaluation of ChAT activity in the hippocampal formation for controls and at 2,8, and $30 \mathrm{DPL}$. ChAT activity represents the quantity of $\mathrm{ACh}$ formed in $\mathrm{nmol} / \mathrm{mg}$ protein/ $\mathrm{hr}$. All assays were performed in duplicate. Data are mean \pm SEM values from three hippocampi for each DPL (control, 2, 8, 30).

of nicotinic receptors on terminals of the perforant path is further supported by the presence of high levels of mRNA for various nicotinic receptor subunits in layer II of the medial entorhinal area, which gives rise to the medial perforant path to the dentate gyrus (Wada et al., 1989). Muscarinic- $M_{1}$ receptor binding sites, which are located predominantly postsynaptically (Potter et al., 1984; Quirion, 1985; Spencer et al., 1986), also did not follow the profile of AChE staining intensification in the hippocampal formation after ECL. We also evaluated the density of muscarinic- $\mathrm{M}_{2}\left({ }^{3} \mathrm{H}-\mathrm{AF}-\mathrm{DX}\right.$ 384) and muscarinic $\mathrm{M}_{1}$ ( ${ }^{3} \mathrm{H}$-pirenzepine) binding sites up to $64 \mathrm{DPL}$ and no changes were observed in the molecular layer of the hippocampus (I. Aubert, J. Poirier, S. Gauthier, and R. Quirion, unpublished observations). Taken together, these results suggest that the increase in hippocampal AChE staining observed post-ECL is unlikely to relate to a general neurochemical reorganization of cholinergic synapses, at least up to 2 months postlesions.

A direct involvement of the cholinergic septohippocampal pathway in the increased AChE staining seen following ECL is also doubtful. It is well established that dramatic decreases in AChE staining or activity are observed in animals with fimbriafornix lesions (Shute and Lewis, 1963; Lynch et al., 1972; StormMathisen, 1974). However, in animals that received combined lesions of the septum and the entorhinal cortex, an increase of AChE staining in the molecular layer of the hippocampus was still observed (Chen et al., 1983). The source of the axons that are sprouting remains unknown, but in contrast to data reported previously (Lynch et al., 1972), the presence of an intact septohippocampal pathway may not be a prerequisite to increase AChE staining in the molecular layer of the hippocampus following ECL (Chen et al., 1983). Furthermore, animals with a septohippocampal lesion that received in the same surgical session an additional destruction of the granule cells showed a pronounced increase in the intensity of the AChE staining in the outer molecular layer of the dentate gyrus (McKeon et al., 1989). However, the increase in AChE staining occurred without a corresponding change in ChAT immunoreactivity (McKeon ct al., 1989). This is consistent with the data reported here; no correlation was found between AChE staining and ChAT activity at any DPI. 
Consequently, the nature of the AChE-positive sprouting fibers observed in the molecular layer of the dentate gyrus postECL remains to be elucidated. AChE-positive, noncholinergic interneurons are present in several areas of the hippocampus, predominantly in the hilar region (Shute and Lewis, 1966), where perikarya of sprouting commissural-associational fibers are concentrated. A significant portion of these interneurons may be GABAergic and cholinoceptive, as for interneurons of the rat cerebral cortex (Hallanger et al., 1986). In addition, neurotensinbinding sites have a distribution which resembles that of $\mathrm{AChE}$ staining in certain areas of the rat (Moyse et al., 1987) and human (Szigethy et al., 1990) brain. This is of interest since it was proposed that $\mathrm{AChE}$ can play a role in the metabolism of certain neuropeptides (Chubb et al., 1980; Small and Chubb, 1988; Checler and Vincent, 1989; Small, 1989) and in the regulation of cellular proliferation and neurite outgrowth (Small, 1990). However, most of these newly proposed roles for AChE are still under debate (Checler and Vincent, 1989; Small, 1989, 1990; Checler, 1990). It will thus be of interest to investigate the status of GABAergic and peptidergic hippocampal reinnervation post-ECL and to correlate any changes with those established for $\mathrm{AChE}$.

Interactions between NGF, its receptors, and cholinergic sprouting in the ECL model also deserve to be discussed. NGFlike growth-promoting activity, NGF immunoreactivity, and NGF receptor immunoreactivity have been shown to increase in the dentate gyrus following ECL (Crutcher and Collins, 1986; Gómez-Pinila et al., 1987; Conner et al., 1991). This could suggest that NGF can trigger the septal cholinergic sprouting into the dentate gyrus, as cholinergic neurons are known to be highly responsive to NGF (Gage et al., 1990; Hefti et al., 1990). A recent study supports this hypothesis since it shows that antibody to NGF inhibits collateral cholinergic sprouting of septohippocampal fibers following ECL (Van der Zee et al., 1992). However, these authors have characterized the presumptive cholinergic sprouting in the hippocampus solely on the basis of $\mathrm{AChE}$ staining. In addition, other types of hippocampal deafferentation such as septal or fimbria-fornix lesions, known to produce drastic decreases in AChE staining in the hippocampus, still caused increases in NGF content or activity in the dentate gyrus (Collins and Crutcher, 1985; Gasser et al., 1986; Weskamp et al., 1986). Therefore, it is more likely that increased NGFlike activity and immunoreactivity following ECL (Crutcher and Collins, 1986; Conner et al., 1991) result from a more general mechanism in which a degenerative process in the hippocampus mechanism in which a degenerative process in the hippocampus produces sequential events leading to the secretion of NGF.

In summary, these observations suggest that the increased AChE staining seen in response to deafferentation might be due to the sprouting of noncholinergic, nonseptohippocampal, intrinsic or extrinsic afferents to the molecular layer of the dentate gyrus. Whilc the concomitant shrinkage of the molccular layer seen in ECL animals (Storm-Mathisen, 1974; Lynch et al., 1975; Nadler et al., 1977; Scheff et al., 1980; Stanfield and Cowan, 1982) may have contributed to some alterations in the markers examined, the marked increase in AChE staining is in clear contrast with the absence of significant and consistent pre- and postsynaptic alterations of various cholinergic markers. On the other hand, if AChE-positive sprouting fibers are in fact cholinergic, our data suggest that the newly formed synapses are unlikely to be adequately organized since the cholinergic markers examined were not altered consistently following ECL, even after 30 DPL. Further experiments are necessary to clarify the nature of the sprouting AChE fibers in the ECL model of synaptic plasticity.

\section{References}

Abood LG, Grassi S (1986) [ $\left.{ }^{3} \mathrm{H}\right]$ methylcarbamylcholine, a new radioligand for studying brain nicotinic receptors. Biochem Pharmacol 35:4199-4202.

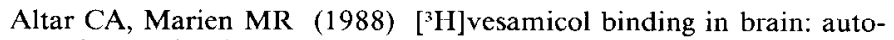
radiographic distribution, pharmacology, and effects of cholinergic lesions. Synapse 2:486-493.

Amaral DG, Avendano C, Cowan WM (1980) The effects of neonatal 6-hydroxydopamine treatment on morphological plasticity in the dentate gyrus of the rat following entorhinal cortex lesions. J Comp Neurol 194:171-191.

Araujo DM, Lapchak PA, Robitaille Y, Gauthier S, Quirion R (1988a) Differential alteration of various cholinergic markers in cortical and subcortical regions of human brain in Alzheimer's disease. J Neurochem 50:1914-1923.

Araujo DM, Lapchak PA, Collier B, Quirion R (1988b) Characterization of $N-\left[{ }^{3} \mathrm{H}\right]$ methylcarbamylcholine binding sites and effect of $N$-methylcarbamylcholine on acetylcholine release in rat brain. J Neurochem 51:292-299.

Araujo DM, Lapchak PA, Collier B, Quirion R (1989) $N-\left[{ }^{3} \mathrm{H}\right]-$ methylcarbamylcholine binding sites in the rat and human brain: relationship to functional nicotinic autoreceptors and alterations in Alzheimer's disease. In: Progress in brain research, Vol 79 (Nordberg A, Fuxe K, Holmstedt B, Sundwall A, eds), pp 345-352. London: Elsevier.

Aubert I, Araujo DM, Cécyre D, Robitaille Y, Gauthier S, Quirion R (1992a) Comparative alterations of nicotinic and muscarinic binding sites in Alzheimer's and Parkinson's diseases. J Neurochem 58:529541.

Aubert I, Cécyre D, Gauthier S, Quirion R (1992b) Characterization and autoradiographic distribution of [ $\left.{ }^{3} \mathrm{H}\right] \mathrm{AF}-\mathrm{DX} 384$ binding to putative muscarinic M2 receptors in the rat brain. Eur J Pharmacol 217 : 173-184.

Baisden RH, Woodruff ML, Hoover DB (1984) Cholinergic and noncholinergic septo-hippocampal projections: a double-label horseradish peroxidase-acetylcholine esterase study in the rabbit. Brain Res 290:146-151.

Boksa P, Quirion R (1987) $\left[{ }^{3} \mathrm{H}\right] N$-methyl-carbamylcholine, a new radioligand specific for nicotinic acetylcholine receptors in brain. Eur J Pharmacol 139:323-333.

Checler F (1990) Non-cholinergic actions of acetylcholinesterases: a genuine peptidase function or contaminating proteases? Trends Biochem Sci 15:337-338.

Checler F, Vincent J-P (1989) Peptidasic activities associated with acetylcholinesterase are due to contaminating enzymes. J Neurochem 53:924-928.

Chen L-L, Van Hoesen GW, Barnes CL, West JR (1983) Enhanced acetylcholinesterase staining in the hippocampal perforant pathway zone after combined lesions of the septum and entorhinal cortex Brain Res 272:354-359.

Chubb IW, Hodgson AJ, White GH (1980) Acetylcholinesterase hydrolyses substance P. Neuroscience 5:2065-2072.

Clarke PBS, Schwartz RD, Paul SM, Pert CB, Pert A (1985) Nicotinic binding in rat brain: autoradiographic comparison of $\left[{ }^{3} \mathrm{H}\right]$ acetylcholine, $\left[{ }^{3} \mathrm{H}\right]$ nicotine, and [125I]-alpha-bungarotoxin. J Neurosci 5:1307-1315.

Collins F, Crutcher KA (1985) Neurotrophic activity in the adult rat hippocampal formation: regional distribution and increase after septal lesion. J Neurosci 5:2809-2814.

Conner JM, Fass-Holmes B, Varon S (1991) Time course of changes in nerve growth factor immunoreactivity (NGFi) in the dentate gyrus following entorhinal cortex lesion. Soc Neurosci Abstr 17:139.

Cotman CW, Matthews DA, Taylor D, Lynch G (1973) Synaptic rearrangement in the dentate gyrus: histochemical evidence of adjustments after lesions in immature and adult rats. Proc Natl Acad Sci USA 70:3473-3477.

Crutcher KA, Collins F (1986) Entorhinal lesions result in increased nerve growth factor-like growth-promoting activity in medium conditioned by hippocampal slices. Brain Res 399:383-389.

Davies P (1979) Neurotransmitter-related enzymes in senile dementia of the Alzheimer type. Brain Res 171:319-327.

Diebler M-F, Morot Gaudry-Talarmain Y (1989) AH5183 and cetie- 
dil: two potent inhibitors of acetylcholine uptake into isolated synaptic vesicles from Torpedo marmorata. J Neurochem 52:813-821.

Entzeroth M, Mayer N (1990) Labeling of rat heart muscarinic receptors using the new M2 selective antagonist [ $\left.{ }^{3} \mathrm{H}\right] \mathrm{AF}-\mathrm{DX} 384$. Biochem Pharmacol 40:1674-1676.

Fagan AM, Gage FH (1990) Cholinergic sprouting in the hippocampus: a proposed role for IL-1. Exp Neurol 110:105-120.

Fonnum $F$ (1969) Radiochemical micro assays for the determination of choline acetyltransferase and acetylcholinesterase activities. Biochem J 1 15:465-472.

Gage FH, Buzsaki G, Armstrong DM (1990) NGF-dependent sprouting and regeneration in the hippocampus. Prog Brain Res 83:357370.

Gasser UE, Weskamp G, Otten U, Dravid AR (1986) Time course of the elevation of nerve growth factor (NGF) content in the hippocampus and septum following lesions of the septohippocampal pathway in rats. Brain Res 376:351-356.

Geddes JW, Monaghan DT, Cotman CW, Lott IT, Kim RC, Chui HC (1985) Plasticity of hippocampal circuitry in Alzheimer's disease. Science 230:1179-1181.

Gómez-Pinila F, Cotman CW, Nieto-Sampedro M (1987) NGF receptor immunoreactivity in rat brain: topographic distribution and response to entorhinal ablation. Neurosci Lett 82:260-266.

Greenfield SA (1991) A noncholinergic action of acetylcholinesterase (AChE) in the brain: from neuronal secretion to the generation of movement. Cell Mol Neurobiol 11:55-77.

Hallanger AE, Wainer BH, Rye DB (1986) Colocalization of gammaaminobutyric acid and acetylcholinesterase in rodent cortical neurons. Neuroscience 19:763-769.

Hefti F, Knusel B, Michel PP (1990) Selective and non-selective trophic actions on central cholinergic and dopaminergic neurons in vitro. In: Progress in brain research, Vol 86 (Coleman P, Higgins G, Phelps C, eds), pp 145-155. London: Elsevier.

Henke H, Lang W (1983) Cholinergic enzymes in neocortex, hippocampus and basal forebrain of non-neurological and senile dementia of Alzheimer-type patients. Brain Res 267:281-291.

Hoff SF, Scheff SW, Kwan AY, Cotman CW (1981) A new type of lesion-induced synaptogenesis: I. Synaptic turnover in non-denervated zones of the dentate gyrus in young adult rats. Brain Res 222 $1-13$.

Hyman Bl, Kromer LJ, Van Hoesen GW (1987) Reinnervation of the hippocampal perforant pathway zone in Alzheimer's disease. Ann Neurol 21:259-267.

Karnovsky MJ, Roots L (1964) A "direct-coloring" thiocholine method for cholinesterases. J Histochem Cytochem 12:219-221.

Kellar KJ, Martino AM, Hall DP Jr, Schwartz RD, Taylor RL (1985) High-affinity binding of $\left[{ }^{3} \mathrm{H}\right]$ acetylcholine to muscarinic cholinergic receptors. J Neurosci 5:1577-1582.

Lapchak PA, Araujo DM, Quirion R, Collicr B (1989) Binding sites of $\left[{ }^{3} \mathrm{H}\right]$ AF-DX 116 and effect of AF-DX 116 on endogenous acetylcholine release from rat brain slices. Brain Res 496:285-294.

Lasher SS, Wilson RC, Steward O (1980) Coincidence of AChE-containing and supramamillary nucleus projections to the supragranular layer of the rat dentate gyrus. Soc Neurosci Abstr 6:87.

Levey AI, Wainer BH, Mufson EJ, Mesulam M-M (1983) Co-localization of acetylcholinesterase and choline acetyltransferase in the rat cerebrum. Neuroscience 9:9-22.

Levey AI, Wainer BH, Rye DB, Mufson EJ, Mesulam M-M (1984) Choline acetyltransferase-immunoreactive neurons intrinsic to the rodent cortex and distinction from acetylcholinesterase-positive neurons: Neuroscience 13:341-353.

Lowry OH, Rosebrough NJ, Farr AL, Randall RJ (1951) Protein measurement with the Folin phenol reagent. J Biol Chem 193:265275.

Lynch G, Matthews DA, Mosko S, Parks T, Cotman C (1972) Induced acetylcholinesterase-rich layer in rat dentate gyrus following entorhinal lesions. Brain Res 42:311-318.

Lynch $G$, Rose $G$, Gall C, Cotman CW (1975) The response of the dentate gyrus to partial deafferentation. In: Golgi centennial symposium proceedings (Santini M, ed), pp 505-517. New York: Raven.

Lynch G, Gall C, Rose G, Cotman C (1976) Changes in the distribution of the dentate gyrus associational system following unilateral or bilateral entorhinal lesions in the adult rat. Brain Res 110:57-71.

Lynch $\mathrm{G}$, Rose $\mathrm{G}$, Gall $\mathrm{C}$ (1978) Anatomical and functional aspects of septo-hippocampal projections. In: CIBA Foundation symposium,
Vol 58, Functions of the septo-hippocampal system, pp 5-20. Amsterdam: Elsevier/North-Holland.

Marien MR, Parsons SM, Altar CA (1987) Quantitative autoradiog. raphy of brain binding sites for the vesicular acetylcholine transport blocker 2-(4-phenylpiperidino) cyclohexanol (AH5183). Proc Natl Acad Sci USA 84:876-880.

Mash DC, Flynn DD, Potter LT (1985) Loss of M2 muscarine receptors in the cerebral cortex in Alzheimer's disease and experimental cholinergic denervation. Science 228:1115-1117.

Matthews DA, Cotman C, Lynch G (1976a) An electron microscopic study of lesion-induced synaptogenesis in the dentate gyrus of the adult rat. I. Magnitude and time course of degeneration. Brain Res 115:1-21.

Matthews DA, Cotman C, Lynch G (1976b) An electron microscopic study of lesion-induced synaptogenesis in the dentate gyrus of the adult rat. II. Reappearance of morphologically normal synaptic contacts. Brain Res 115:23-41.

McKeon RJ, Vietje BP, Wells J (1989) Increase in acetylcholinesterase in the molecular layer of the dentate gyrus in the absence of septal inputs following selective granule cell lesions. Brain Res 503:317321.

Mesulam M-M, Geula C (1991) Acetylcholinesterase-rich neurons of the human cerebral cortex: cytoarchitectonic and ontogenetic patterns of distribution. J Comp Neurol 306:193-220.

Miller JH, Gibson VA, McKinney M (1991) Binding of [ $\left.{ }^{3} \mathrm{H}\right] A F-D X$ 384 to cloned and native muscarinic receptors. J Pharmacol Exp Ther 259:601-607.

Monaghan DT, Mena EE, Cotman CW (1982) The effect of entorhinal cortical ablation on the distribution of muscarinic cholinergic receptors in the rat hippocampus. Brain Res 234:480-485.

Moyse E, Rostène W, Vial M, Leonard K, Mazella J, Kitabgi P, Vincent J-P, Beaudet A (1987) Distribution of neurotensin binding sites in rat brain: a light microscopic radioautographic study using monoiodo $\left[{ }^{125}\right]$ Tyr3-neurotensin. Neuroscience 22:525-536.

Nadler JV, Cotman CW, Lynch GS (1973) Altered distribution of choline acetyltransferase and acetylcholinesterase activities in the developing rat dentate gyrus following entorhinal lesion. Brain Res 63: 215-230.

Nadler JV, Cotman CW, Lynch GS (1977) Histochemical evidence of altered development of cholinergic fibers in the rat dentate gyrus following lesions. I. Time course after complete unilateral entorhinal lesion at various ages. J Comp Neurol 171:561-588.

Parsons SM, Bahr BA, Gracz LM, Kaufman R, Kornreich WD, Nilsson L, Rogers GA (1987) Acetylcholine transport: fundamental properties and effects of pharmacological agents. In: Annals of the New York Academy of Sciences, Vol 493, Cellular and molecular biology of hormone- and neurotransmitter-containing secretory vesicles (Johnson RG Jr, ed), pp 220-233. New York: NY Academy of Sciences.

Paxinos G, Watson C (1982) The rat brain in stereotaxic coordinates New York: Academic.

Perry EK, Perry RH, Smith CJ, Purohit D, Bonham J, Dick DJ, Candy JM, Edwardson JA, Fairbairn A (1986) Cholinergic receptors in cognitive disorders. Can J Neurol Sci 13:521-527.

Poirier J, Nichols NR (1991) Alteration of hippocampal RNA prevalence in response to deafferentation. In: Methods in neurosciences, Vol 7, Lesions and transplantation (Conn PM, ed), pp 182-199. San Diego: Academic.

Potter LT, Flynn DD, Hanchett HE, Kalinoski DL, Luber-Narod J, Mash DC (1984) Independent M1 and M2 receptors: ligands, autoradiography and functions. Trends Pharmacol Sci 5:22-31.

Quirion R (1985) Comparative localization of putative pre- and postsynaptic markers of muscarinic cholinergic nerve terminals in rat brain. Eur J Pharmacol 111:287-289.

Quirion R (1987) Characterization and autoradiographic distribution of hemicholinium-3 high-affinity choline uptake sites in mammalian brain. Synapse 1:293-303.

Quirion R, Boksa P (1986) Autoradiographic distribution of muscarinic $\left[{ }^{3} \mathrm{H}\right]$ acetylcholine receptors in rat brain: comparison with antagonists. Eur J Pharmacol 123:170-172.

Quirion R, IJammer RP Jr, Herkenham M, Pert CB (1981) Phencyclidine (angel dust) $/ \sigma$ "opiate" receptor: visualization by tritium-sensitive film. Proc Natl Acad Sci USA 78:5881-5885.

Quirion R, Araujo D, Regenold W, Boksa P (1989) Characterization and quantitative autoradiographic distribution of $\left[{ }^{3} \mathrm{H}\right]$ acetylcholine 
muscarinic receptors in mammalian brain. Apparent labelling of an M2-like receptor sub-type. Neuroscience 29:271-289.

Rainbow TC, Parsons B, Wieczorek CM (1984) Quantitative autoradiography of $\left[{ }^{3} \mathrm{H}\right]$ hemicholinium- 3 hinding sites in rat brain. Fur $\mathbf{J}$ Pharmacol 102:195-196.

Raiteri M, Leardi R, Marchi M (1984) Heterogeneity of presynaptic muscarinic receptors regulating neurotransmitter release in the rat brain. J Pharmacol Exp Ther 228:209-214.

Ramón y Cajal S (1901) Estudios sobre la corteza cerebral humana. IV. Estructura de la corteza cerebral olfativa del hombre y mamíferos. Trab Lab Invest Biol Univ Madrid 1:1-140.

Ransmayr G, Cervera P, Ruberg M, Hersh LB, Duyckaerts C, Hauw J-J, Delumeau C, Agid Y (1989) Choline acetyltransferase-like immunoreactivity in the hippocampal formation of control subjects and patients with Alzheimer's disease. Neuroscience 32:701-714.

Reisine TD, Yamamura HI, Bird ED, Spokes E, Enna SJ (1978) Preand postsynaptic neurochemical alterations in Alzheimer's disease. Brain Res 159:477-481.

Rinne JO, Lönnberg P, Marjamäki P, Rinne UK (1989) Brain muscarinic receptor subtypes are differently affected in Alzheimer's disease and Parkinson's disease. Brain Res 483:402-406.

Scheff SW, Benardo LS, Cotman CW (1980) Decline in reactive fiber growth in the dentate gyrus of aged rats compared to young adult rats following entorhinal cortex removal. Brain Res 199:21-38.

Schwartz RD (1986) Autoradiographic distribution of high affinity muscarinic and nicotinic cholinergic receptors labeled with $\left[{ }^{3} \mathrm{H}\right]$ acetylcholine in rat brain. Life Sci 38:2111-2119.

Senut MC, Roudier M, Davous P, Fallet-Bianco C, Lamour Y (1991) Senile dementia of the Alzheimer type: is there a correlation between entorhinal cortex and dentate gyrus lesions? Ann Neurol 82:306-315.

Shute CCD, Lewis PR (1963) Cholinesterase-containing systems of the brain of the rat. Nature 199:1 160-1164.

Shute CCD, Lewis PR (1966) Electron microscopy of cholinergic terminals and acetylcholine esterase containing neurons in the hippocampus of rats. Z Zellforsch Mikrosk Anat 69:334-343.

Small DH (1989) Acetylcholinesterases: zymogens of neuropeptide processing enzymes? Neuroscience 29:241-249.

Small DH (1990) Non-cholinergic actions of acetylcholinesterases: proteases regulating cell growth and development? Trends Biochem Sci 15:213-216.

Small DH, Chubb IW (1988) Identification of a trypsin-like site associated with acetylcholinesterase by affinity labelling with $\left[{ }^{3} \mathrm{H}\right]$ diisopropyl fluorophosphate. J Neurochem 51:69-74.

Spencer DG Jr, Horváth E, Traber J (1986) Direct autoradiographic determination of M1 and M2 muscarinic acetylcholine receptor distribution in the rat brain: relation to cholinergic nuclei and projections. Brain Res 380:59-68.

Stanfield BB, Cowan WM (1982) The sprouting of septal afferents to the dentate gyrus after lesions of the entorhinal cortex in adult rats. Brain Res 232:162-170.
Steward O, Scoville SA (1976) Cells of origin of entorhinal cortical afferents to the hippocampus and fascia dentata of the rat. J Comp Neurol 169:347-370.

Steward O, Cotman CW, Lynch GS (1974) Growth of a new fiber projection in the brain of adult rats: re-innervation of the dentate gyrus by the contralateral entorhinal cortex following ipsilateral entorhinal cortex lesions. Exp Brain Res 20:45-66.

Storm-Mathisen J (1974) Choline acetyltransferase and acetylcholinesterase in fascia dentata following lesion of the entorhinal afferents. Brain Res 80:181-197.

Swanson LW, Simmons DM, Whiting PJ, Lindstrom J (1987) Immunohistochemical localization of neuronal nicotinic receptors in the rodent central nervous system. J Neurosci 7:3334-3342.

Szigethy E, Quirion R, Beaudet A (1990) Distribution of 125I-neurotensin binding sites in human forebrain: comparison with the localization of acetylcholinesterase. J Comp Neurol 297:487-498.

Tuček S (1978) Choline acetyltransferase. In: Acetylcholine synthesis in neurons (Tuček S, ed), pp 3-32. London: Chapman and Hall

Van der Zee CEEM, Fawcett J, Diamond J (1992) Antibody to NGF inhibits collateral sprouting of septohippocampal fibers following entorhinal cortex lesion in adult rats. J Comp Neurol 326:91-100.

Vickroy TW, Roeske WR, Gehlert DR, Wamsley JK, Yamamura HI (1985) Quantitative light microscopic autoradiography of $\left[{ }^{3} H\right]$ hemicholinium-3 binding sites in the rat central nervous system: a novel biochemical marker for mapping the distribution of cholinergic nerve terminals. Brain Res 329:368-373.

Wada E, Wada K, Boulter J, Deneris E, Heinemann S, Patrick J, Swanson LW (1989) Distribution of alpha2, alpha3, alpha4, and beta2 neuronal nicotinic receptor subunit mRNAs in the central nervous system: a hybridization histochemical study in the rat. J Comp Neurol 284:314-335.

Wainer BH, Levey AI, Rye DB, Mesulam M-M, Mufson FJ (1985) Cholinergic and non-cholinergic septohippocampal pathways. Neurosci Lett 54:45-52.

Watson M, Roeske WR, Yamamura HI (1982) [ $\left.{ }^{3} \mathrm{H}\right]$ pirenzepine selectively identifies a high affinity population of muscarinic cholinergic receptors in the rat cerebral cortex. Life Sci 31:2019-2023.

Watson M, Vickroy TW, Roeske WR, Yamamura HI (1984) Subclassification of muscarinic receptors based upon the selective antagonist pirenzepine. Trends Pharmacol Sci 5:9-11.

Weiler MH (1989) Muscarinic modulation of endogenous acetylcholine release in rat neostriatal slices. J Pharmacol Exp Ther 250:617623 .

Weskamp G, Gasser UE, Dravid AR, Otten U (1986) Fimbria-fornix lesion increases nerve growth factor content in adult rat septum and hippocampus. Neurosci Lett 70:121-126.

Yamada S, Gehlert DR, Hawkins KN, Năkayama K, Roeske WR, Yamamura HI (1987) Autoradiographic localization of nicotinic receptor binding in rat brain using $\left[{ }^{3} \mathrm{H}\right]$ methylcarbamylcholine, a novel radioligand. Life Sci 41:2851-2861. 